\title{
From Borderland to Border
}

On April 4, 1867, the vice minister of the Shengjing Board of Revenue, E-le-he-bu, reported to the Tongzhi emperor (r. 1862-74) that a steadily increasing number of civilian farmers were illegally cultivating prohibited land outside the eastern line of the Willow Palisade. According to his letter, the illegal settlers had even approached the Shengjing office and volunteered to pay taxes, following the precedent of Jilin, where illegal famers were already allowed to do so. E-le-he-bu had responded cautiously to the farmers' willingness to pay taxes, since their settlement in the prohibited area outside the palisade was a serious violation of Qing restriction policy in the northeast. He was also well aware that the area was located near the boundary with the Chosonn and therefore required special consideration; he needed to check whether the settlement could cause problems with the Chosonn court. ${ }^{1}$ E-le-he-bu's report was forwarded to the six boards and the Grand Council for further discussion. The high officials in Beijing emphasized that Shengjing was the sacred birthplace of the Qing empire and that several thousand $l i$ of land and mountains there had always been protected by the palisade. Simultaneously, however, they recognized that there were numerous people living outside the palisade and that these people made their living by cultivating the land and logging timber. The officials were rightly concerned that if the illegal settlers were forced to evacuate the prohibited territory, they would lose their livelihoods and likely end up rebelling. The Qing court thus had to find a solution that would place these settlers under the state's authority but also protect the prohibited land near the boundary with the Chosŏn. ${ }^{2}$ 
As early as 1863, the Jinzhou garrison lieutenant general (fudutong), En-he, had informed the emperor of the situation in the area between the Willow Palisade and the Yalu River in the following way:

Because of the wide land and the deep mountains in this region, thorough investigation and patrolling are nearly impossible. Trespassers have long been sneaking into the area, first to hunt and to log, and later to mine for gold and to cultivate land. These days, vagabonds from Zhili and Shandong are coming here and forming gangs to cause trouble. Previously they built houses and tilled the land only in the deep mountains, but now there is no limit to the illegal settlement, and it is spreading widely over hundreds $l i$ of land. Patrolling soldiers are few in number and weak in power, so they are unable to stop these criminals. The prevention of access to the area near the boundary is gradually becoming ineffectual; the land outside the palisade is being reclaimed without any official effort [by the state]. ${ }^{3}$

En-he's last sentence provides a succinct description of the illegal settlement that was taking place at the Qing-Chosŏn boundary already in the late nineteenth century. No matter how much the Qing and Chosŏn authorities tried to restrict access to the area, the vast territory near the Yalu River had gradually filled with illegal farmers hungry for land.

This chapter examines the ways in which the Qing and Chosŏn courts discussed the increasing illegal settlement at the boundary where ginseng disappeared and how Korean immigrants north of the Tumen River led the two neighbors to a series of negotiations to establish the exact limits of their territories in the late nineteenth century. The chapter begins by tracing the changes in the Qing ginseng monopoly in the nineteenth century. As ginseng became scarce and people involved in its business expected little profit, the Qing court failed to maintain its monopolistic control over it. The depletion of ginseng in Manchuria came along with an influx of Chinese farmers in the restricted margins of the empire. From the nineteenth century on, the Qing prohibition of civilian settlement in the northeast gradually broke down; the growing number of Chinese immigrants effectively invalidated the state's restrictions. In addition, Russia undermined Qing rule over land and tribal people in Manchuria through a series of new treaties. Under the circumstances, the only way for the Qing court to uphold its territorial sovereignty in Manchuria was to encourage Chinese farmers to move to the region and thereby fill it with Qing subjects. The previously restrictive Qing Manchuria policy, consisting mainly of the stationing of banner soldiers and unwavering insistence on the evacuation of the region, was gradually replaced by a new plan of "recruiting civilians to populate, cultivate, and settle," a policy that was known as yimin shibian.

The second focus in this chapter is on the transformation of the nature of QingChosŏn political relations and territorial boundaries. As early as the nineteenth century, the area near the Yalu and Tumen Rivers and Changbaishan had lost its 
fame for rich ginseng production. Instead of ginseng hunters, it was civilian farmers who were increasingly seen in the region. This supposedly empty land invited not only Chinese immigration but also Korean settlers, and consequently the Qing government began to claim jurisdictional authority over the Korean immigrants. Debates over the Korean settlers living north of the Tumen River became more complicated because they took place at the very time when Qing-Chosŏn relations were being reinterpreted and renegotiated. The Qing court of the late nineteenth century wanted to retain the absolute power over the Chosŏn court that it had held for centuries; newly emerging international relations in East Asia, however, caused the Chosŏn to reevaluate its traditional respect for the suzerain Qing power in order to protect Korean subjects living north of the Tumen River. This chapter demonstrates that this change in Qing-Chosŏn relations led to a revision of their previous conceptions and practices of boundary and sovereignty. The new environment surrounding the two countries no longer tolerated the borderland that the Qing and the Chosŏn shared, and instead led to the emergence of a clearly defined border.

\section{DISAPPEARING GINSENG, INCREASING PEOPLE}

Until the late eighteenth century, Manchurian ginseng continued to claim an important position in Qing state revenue. In 1753, the Qing state's total revenue from customs duties had been 4,330,00o liang of silver. In 1760 the Qing court issued six thousand ginseng permits and allocated a quota of six liang of ginseng per permit, 36,000 liang in total. This amount was equivalent to 1,440 , ooo liang of silver, since the market price of a liang of ginseng at the time was forty liang of silver. ${ }^{4}$

As table 3 shows, however, the number of issued ginseng permits plummeted and the ginseng business declined from the late eighteenth century onward. The primary reason for this trend was the overharvesting and subsequent depletion of ginseng stocks. The depletion was a predictable result of the continuous exploitation of this natural resource over the centuries. Shortages of natural resources in Manchuria throughout the period 1750 to 1850 applied not only to ginseng but also to pheasants, storks, pine nuts, and sable skins. This phenomenon indicates that it was imperial foraging, rather than Han Chinese poaching, that had played a primary role in resource depletion in Manchuria. ${ }^{5}$ The government imposed various regulations in an effort to protect the resource base, such as enforcing "resting" periods for mountains, rivers, and forests; strengthening control over gathering operations; erecting walls and fences; dispatching patrols to strategic points to deter poaching; and arresting poachers, illegal cultivators, and black market operators. ${ }^{6}$ However, the policy of resting ginseng-producing mountains, for example, amounted merely to a temporary halt in the issuance of ginseng-gathering permits and was thus ineffective in combating illegal poaching. ${ }^{7}$ The depletion of ginseng stocks also wreaked 
TABLE 3 Change in the number of ginseng permits from the 1760 s to 1850 s.

\begin{tabular}{ccc}
\hline Year & Number of permits printed & Number of permits issued \\
\hline 1760 & 10,000 & 6,000 \\
1777 & 6,000 & 2,900 \\
1789 & 5,000 & 2,330 \\
1799 & 2,287 & Unknown \\
1846 & 1,752 & Unknown \\
1852 & 753 & 632 \\
\hline
\end{tabular}

SOURCE: Wang, "Qingdai dongbei caishenye," 191.

havoc on the state's control over gatherers, licensed merchants, and officials. It was a common practice that the Ginseng Office extended advance loans to gatherers to enable the latter to pay for their expenses; the gatherers were then expected to pay back the loans by selling their surplus ginseng. In actuality, however, every year, 30 to 40 percent of gatherers failed to meet their quota. Facing a shortage of collected ginseng, the Ginseng Office often had to borrow public funds and purchase surplus ginseng from licensed merchants. As the issuance of ginseng permits declined because of the depletion of the stocks, the Ginseng Office's debts increased. ${ }^{8}$

However, even the persistent shortfalls in ginseng resources and the decline in state income did not make the Qing government relax its strict prohibition against ginseng cultivation, which might have provided an alternative source. Fully grown, four- to five-year-old ginseng was hard to find, but younger ginseng was poor in quality and less valued on the market. Therefore, ginseng gatherers sought to transplant young wild ginseng plants into gardens, wait for them to reach maturity, and then harvest the mature ginseng for the state. However, the government was concerned that the widespread cultivation of ginseng would affect its statecontrolled price, and it thus continued to outlaw the practice of ginseng cultivation and to punish ginseng farmers as severely as it did poachers. ${ }^{9}$ In 1802 , when the Jilin military governor proposed legalizing ginseng cultivation, the Jiaqing emperor retorted: "Ginseng grows from the energy of the soil [diling]. If anyone collects a big piece of the root, he should pay it [to the state]; if he cannot find a big one, it is fine for him to report the truth. Why should he use human efforts to cultivate it and cheat [the state]? Only wild ginseng growing in the mountains has medical effects; taking cultivated ginseng is useless." ${ }^{10}$ Despite the emperor's distrust, cultivated ginseng became widespread: in 1810, for example, it represented 60 percent of the ginseng received by the state from Shengjing and 10 percent of the receipts from Jilin. ${ }^{11}$

As poor ginseng harvests caused financial ruin for the gatherers and devastating deficits for the Ginseng Office, the Qing government sought to support the 
ginseng monopoly through the booming business in sorghum liquor (gaoliang jiu). Distilled liquors were already produced as early as the Yuan dynasty; it was the Qing era, however, when the real growth in liquor consumption took place. Chinese liquor was made of sorghum, a grain growing widely in northern China and Manchuria. The sorghum liquor, which was cheap and easy to get drunk on, was particularly popular during the cold winter in Manchuria. ${ }^{12}$ Concerned that its production consumed a large amount of food grains, however, the Qing court imposed a strict prohibition on distilling liquor. In 1726, the Yongzheng emperor lectured his subjects: "The price of rice rose because of the flood in Zhili Province, and I therefore already decreed a prohibition on distilling liquor in the regions outside the passes. However, liquor dealers reportedly run their business in Shengjing as well as at the boundary with Mongolia. Spending food grains on such a wasteful business should be thoroughly proscribed." ${ }^{13}$ By the late eighteenth century, however, when the Qing government was no longer able to obtain the predetermined quota of ginseng from the gatherers, liquor dealers gradually joined the ginseng business as sponsors (baoren) of gatherers, taking responsibility for recruiting and provisioning them and guaranteeing the amount and quality of the ginseng they gathered. In 180o, the Shengjing Ginseng Office formally authorized the liquor business and began to collect taxes from the distillers. In 1807, liquor dealers' sponsorship of ginseng gatherers was officially legalized. ${ }^{14}$

Despite all these efforts, wild ginseng in Manchuria was exhausted to the extent that the government could no longer maintain its monopoly on ginseng collection and trade. The chronic shortage of ginseng caused a serious burden on liquor dealers, who had difficulty in securing the ginseng quotas and eventually refused to sponsor ginseng gatherers. Without the distillers, the government was unable to find takers for a sufficient number of ginseng permits to procure the predetermined quota of ginseng. The rate of depletion of wild ginseng in Manchuria accelerated; the number of ginseng permits issued continued to decline; and the merchants and gatherers could not meet the high ginseng quotas set by the state. All of these factors combined to spell the end for the Qing ginseng monopoly. In 1853, the Qing court finally announced the official end of the state monopoly on ginseng collection and trade. ${ }^{15}$

By the time ginseng disappeared in Manchuria to the extent that the Qing court had to give up the monopoly, circumstances in the northeast had changed radically in terms of both domestic politics and foreign relations. Prior to the middle of the nineteenth century, the wealthy provinces in the Yangzi Delta contributed their surplus to poorer provinces, such as Jilin and Heilongjiang. But these subsidies were greatly depleted due to years of warfare in the south, especially during the Taiping Rebellion (1851-64), which devastated the affluent Jiangnan region. The emptied provincial treasuries caused serious problems in Qing rule in Manchuria, as the poorly paid banner soldiers were unable to impose effective restrictions on 
the increasing illegal immigrants and to establish necessary public order within local societies. ${ }^{16}$ Furthermore, as banner garrison troops in the northeast were mobilized to suppress rebellions in China proper, security in Manchuria was also jeopardized by foreign aggressors, notably Russia. By the mid-nineteenth century, Russia pushed forward a series of expeditions of the Heilongjiang River, where the Qing did not have military power to prevent Russian approaches. In 1858, when Qing forces were in the midst of fighting the Taiping rebels and were also struggling against British and French forces, Russia succeeded in forcing the Qing court to sign the Treaty of Aigun. Two years later, in 1860, the Convention of Beijing confirmed the "[opening of] the entire northern frontier of the Qing empire, from Manchuria to Xinjiang, to Russia's political and commercial influence." By requiring the Qing to cede all lands north of the Heilongjiang and east of the Ussuri to Russia, these two treaties enabled Russia to encroach on Qing Manchuria. ${ }^{17}$

By the 1850 s, the Qing court continued its effort, in vain, to maintain the restriction policy on civilian settlement in Jilin by repeating the old rhetoric of the "place of Manchu origins." However, local military commanders in the northeast had to find ways to meet the new financial shortfalls, and land was the most abundant and readily available resource. Eventually, the Jilin and Heilongjiang authorities began to make a series of proposals to Beijing that the restricted areas should be opened to civilian settlement, and by doing so, money and taxes be collected from the settlers. In 1859, Jilin military governor Jing-chun proposed the opening of the previously prohibited regions of the Suifen and Ussuri Rivers, because of the possible threat that the Russian ships might approach there. He suggested that "if [our] people can gather and settle in the region and take profits from timber logging, hunting, ginseng gathering, and fishing in the deep mountains, the Russians will retreat on their own." The Xianfeng emperor (r. 1850-61) agreed with Jingchun, saying that "it is beneficial that China's subjects should live in China's vast land" (yi Zhongguo zhi kuangtu, ju Zhongguo zhi minren, li zhi suozai), by which people were to protect themselves and foreign aggressions be prevented. ${ }^{18}$ The following year, in 1860, the Qing court opened parts of southern Jilin for civilian settlement, a decision largely considered the first official lifting of the restriction policy in Qing Manchuria. From the 186 os to the 188 os, many prohibited areas in Jilin and Heilongjiang were gradually opened for settlement and the restrictions on civilian settlers became effectively nominal. ${ }^{19}$

The opening of the northeast and the increase in civilian immigrants required a transformation of the administrative system in Manchuria: the Qing government needed a new institutional structure to deal with the increasing civil affairs. In 1875, the acting Shengjing military governor, Chong-shi, suggested that the Shengjing government be restructured to match the administrative system of China proper and to make a necessary response to the increasing numbers of Chinese immigrants. The Guangxu emperor (r. 1875-1908) eventually approved 
his proposal, and the Shenging military governor was granted authority over all affairs involving garrison troops as well as civilian settlers. While increasing the power of the military governor, this reform also sought to limit the privileges of banner garrisons and shift more administrative authority into the hands of civil officials. Between 1877 and 1883, Jilin also carried out an overall reorganization of its government through the efforts of the Jilin military governor, Ming-an. Throughout the 1870 s and the 188 os, new county administrative offices for civilian affairs were established in various places in Shengjing and Jilin. As administrative power was transferred from banner garrisons to civil offices, the primary purpose of the government changed from protecting and nurturing the banner forces to supervising and governing Chinese immigrants. ${ }^{20}$ It was these newly arrived Chinese settlers who began to occupy Manchuria when ginseng grew scarce and the Manchus lost their privilege.

\section{FILLING THE EMPTY LAND}

Just like other regions of Manchuria, the long-prohibited areas near the Chosŏn boundary faced a profound transformation in the nineteenth century, in terms of both environmental conditions and political relations. The region around the Yalu and Tumen Rivers and Changbaishan had claimed a reputation for rich production of high-quality ginseng, which caused the constant trespassing incidents between the Qing and the Chosonn. After the exploitation for centuries, however, the old ginseng mountains in Shenging and Jilin, especially those near the Chosŏn boundary, which had long been harvested, no longer produced much ginseng. And as the ginseng harvest shrank, the number of illegal ginseng hunters also dwindled. By the mid-nineteenth century, there were very few cases reported to Beijing or Seoul for trespassing related to ginseng poaching. Now, it was illegal timber loggers and farmers who were replacing the ginseng poachers and animal hunters in the land north of the Yalu and Tumen Rivers. ${ }^{21}$ The emergence of civilian farmers in the restricted areas at the boundary brought substantial changes in the ideas and practices of this territory that the Qing and the Chosonn had shared. As previous chapters show, it was ginseng that led the two neighbors to an agreement to keep the land at the boundary off-limits to civilian settlers. The Qing wanted to protect the Manchu privilege, which was signified as ginseng, while the Chosŏn hoped to avoid conflicts with the suzerain power by giving up this precious root despite its physical accessibility. When there was ginseng, the land at the boundary was to be restricted for the purpose of preserving both Qing hegemony and Chosŏn sovereignty. As ginseng disappeared and people began to settle there, however, the two neighbors had to reconsider their old agreement to maintain the empty land at the Yalu and Tumen Rivers-as well as their ideas about territory and boundary. 
Two good examples from the 1840 s illustrate the growth of illegal settlements of Chinese farmers near the Yalu River. In 1842, the Chosŏn provincial governor of Hamgyŏng reported to Seoul that Qing subjects were building houses and cultivating land across the Yalu River from the Chosŏn Kanggye and Manpo. In response to the Chosŏn court's request to put a stop to illegal settlement at the boundary, the Shengjing military governor investigated three relevant locations, where 3,300 $m u$ of cultivated land was found along with nearly a hundred thatched huts. Qing soldiers failed to arrest any of the illegal settlers, all of whom ran away, so the soldiers merely destroyed the unauthorized fields and lodgings. The incident reveals that Chinese immigrants were not intruding into the area near the Yalu River only for such temporary activities as ginseng poaching or timber logging; rather, they were establishing permanent settlements and engaging in cultivation. Strikingly, neither the Qing nor the Chosŏn had managed to check these violations until as much as 3,300 $\mathrm{mu}$ of land had been put under the plow. A similar situation was reported in 1846 , only four years later, with the discovery that vast tracts of land in forty different locations across the Yalu River from Chosŏn Kanggye were being cultivated. This time Qing and Chosŏn officials undertook a joint investigation along the middle and lower parts of the Yalu River and arrested three hundred illegal settlers. ${ }^{22}$

Reports about rampant illegal settlement led to an increase in Qing patrols at the boundary with the Chosŏn. Most importantly, the Qing and the Chosŏn agreed to make joint patrols of the boundary a regular, biannual practice. The two governments carried out thirty-eight joint patrols during the years 1849 to 1867. However, all of these efforts to stop illegal settlement and to keep the area off-limits and empty were ineffectual. The Qing and Chosŏn soldiers reported no cases of illegal settlement between 1857 and 1867, but this apparent calm did not reflect the reality in the region. ${ }^{23}$ In 1867 , the Shengjing military governor Du-xinga visited the area outside the palisade and met with Chosŏn officials at Zhongjiang to deal with illegal settlements near the Yalu River. Two years later, Du-xing-a sent a report to the emperor, saying that more than one hundred thousand people were living outside the palisade and had already claimed 96,00o xiang of land. His conclusion was that illegal settlers were now too numerous to be forcibly removed; the only possible solution was to "expand the perimeter of the palisade and legalize settlement in this region." ${ }^{4}$ The Qing court finally had to figure out what to do with this supposedly vacant but actually inhabited land.

Du-xing-a's suggestion to move the palisade toward the Yalu River-that is, to develop the land at the Chosŏn boundary-was, in fact, not new at all. As discussed in chapter 3, two previous Shengjing military governors, Nasutu and Daldangga, had made similar proposals to develop the area near the Yalu River by establishing a new guard post outside the perimeter of the Willow Palisade, but both of their plans had been rejected. But in contrast to the Yongzheng and 
Qianlong emperors, who had decided to acquiesce to the Chosŏn request not to develop the Yalu River region, the Guangxu emperor decided to invalidate the long-standing Qing agreement with the Chosŏn court regarding the management of their boundary. In 1875, the emperor imposed taxation on the already reclaimed land in Dadonggou, located at the mouth of the Yalu River, and also permitted household registration for illegal settlers, whether they were civilians or bannermen: "Small people have long settled in the relevant lands and are now volunteering to pay taxes. The court is willing to show them mercy and forgive their past crimes, helping them make their living." ${ }^{25}$

The next year, in 1876, the Chosŏn court was informed of an imminent plan for the Qing authorities to open new administrative offices near the Yalu River. Not surprisingly, the Chosŏn voiced strong opposition to the plan, as it had to the proposal to establish a military post at Mangniushao in 1746. The court stressed, once again, that development around the Yalu River had long been prohibited and that if offices were built in this land, "people from here and there could easily sneak in, and goods could be freely exchanged, which would soon lead to trouble." ${ }^{26}$ Prompted by the Chosŏn court's opposition, the Guangxu emperor ordered local officials to investigate the situation, just as the Yongzheng and Qianlong emperors had done earlier. In his report of 1877 , the acting Shengjing military governor, Chong-hou, explained that settlement at the Yalu River was rampant and immigration into the region could no longer be halted. From his point of view, state sanction of development in the area was inevitable. ${ }^{27}$ For the purpose of dealing with civilian affairs related to Chinese immigrants in the region, in 1876 and 1877 Chong-hou established new county offices in Xiu'am, Fenghua, Kuandian, Tonghua, and Huairen, many of which were located outside the palisade. ${ }^{28}$ The Chosŏn court's wish that the Qing and the Chosŏn preserve the empty buffer zone between them in order to protect the territory of each had become unrealistic under the strong pressures from Chinese immigration and settlement.

Once the land at the Yalu River was opened for settlement, prohibitions on inhabitation in the Tumen River region were lifted as well. Since being appointed as the acting Jilin military governor in 1877 , Ming-an followed the precedents in Shengjing and reformed the Jilin government to build new civil offices and open land for Chinese immigrants. By 1881, administrative offices were newly opened in Dunhua and Yitong near the Tumen River. In addition to the Jilin military governor, the Guangxu emperor dispatched a Han Chinese official, Wu Dacheng (1835-1902), with the special mission of strengthening military defense and developing land in the regions of Sanxing, Ningguta, and Hunchun. First, promoting the military rank of Hunchun regiment colonel (xieling) to garrison lieutenant general (fudutong), Wu also built an office for land development (zhaokenju) in Hunchun, and enforced an active recruitment of Chinese farmers in Shandong to settle and cultivate land in this northeastern margin. Furthermore, he ordered his 
men to investigate the land north of the Tumen River. ${ }^{29}$ In order to support Wu's efforts to develop land near the Chosŏn boundary, the Qing court also sent a letter to the Chosŏn court, saying, "This development is led by the [Qing] authorities, and therefore [the Chosŏn] local officials should not be worried." ${ }^{\circ}$ By the 188 os, the areas around the Yalu and Tumen Rivers, which had for so long been closed off to civilian access, were formally opened for settlement and cultivation. The gates of the Willow Palisade lost their designated function of controlling people's movements in the restricted area. With the rapidly increasing number of immigrants, the last remainders of the empty space at the boundary between the Qing and the Chosŏn gradually disappeared.

It was not only Chinese farmers who searched for land near the Yalu and Tumen Rivers: a growing number of Koreans crossed the rivers and settled in the area north of the rivers. People living east of Changbaishan, in areas such as Musan, Hoeryŏng, Chongsŏng, and Onsŏng, crossed the Tumen River; those living on the west side of the mountains, especially in the Four Closed Counties, crossed the Yalu River. The Chosŏn court continued to prohibit its Korean subjects from crossing the Yalu and Tumen Rivers without state permission, and local officials were not allowed to get involved with affairs taking place across the rivers unless they were given an order from Seoul. ${ }^{31}$ However, reports of Korean trespassing and illegal settlement north of the rivers continued. In 1866, a group of seventy men and women in Kyŏngwŏn crossed the Tumen before getting arrested and sent back by the Qing soldiers; as many as two hundred Koreans were reported to cross the Tumen and pass through Hunchun to the Russian territory. The Hunchun regiment colonel witnessed that growing number of Koreans immigrants coming to cross the Tumen:

Many guard posts have reported that Koreans in a small group of three to five, or in a big group of several dozens with families, continue to come passing guard posts [in the Hunchun area]. They are heading to the south of Hunchun in search of gold or cultivable land.... [So far] no civilians have lived in Hunchun; no order to open land has been received. If they are not evicted now, it will be difficult to get rid of them later. ${ }^{32}$

Despite such warnings from local Qing officials, illegal Korean incursions and settlement remained on the rise. It was in the late nineteenth century that references to the so-called Kando (C. Jiandao) - a name indicating contemporary Yanbian in Jilin-first appeared. The Kando region was sometimes used to refer to all of Manchuria, but more typically the region north of the Yalu River was called Western Kando and the region north of the Tumen Northern Kando. ${ }^{33}$ It has been said that Korean immigration towns in Western Kando appeared in the 186 os and 1870s. ${ }^{34}$ The visible presence of Korean settlements north of the Yalu River was, in fact, officially recognized by the local Chosŏn authorities. In 1871, Cho Wihyŏn, the Chosŏn 
county magistrate (K. kunsu) of Huch'ang in P'yŏngan Province, sent his troops to evict Qing intruders who had entered Chosŏn territory illegally in order to log timber in Samsu and Kapsan. The next year, he dispatched three military agents north of the Yalu River to collect information about the areas of Jian, Tonghua, and the Hun River, also known as the Tunggiya River during the period when Möngke Temür had lived. Their travel report for July 5 to August 13, 1872-later titled Diary of North of the River (K. Kangbuk ilgi)-shows the conditions of Korean immigrants in Qing territory at that time. ${ }^{35}$ According to the diary, six to seven thousand Koreans had crossed over to the north side of the Yalu and settled in the area around the Hun River outside the Willow Palisade. Most of the Korean immigrants who settled in Qing territory during the famine of 1869 to 1870 came to be called "false Qing subjects" (K. kaho), because they adopted Qing hairstyles and clothing. ${ }^{36}$

The north of the Tumen was also gradually filled with Korean immigrants. When the famine devastated Hamgyong Province, many people were forced to look for a source of livelihood elsewhere and crossed the Tumen River on search of land to cultivate. In addition to natural disasters, tax increases by corrupt local officials were another reason cited to explain why people had to leave their homes. ${ }^{37}$ By this time, the punishments imposed by the Chosŏn court on trespassers became more lenient, creating yet another incentive for people to cross the river. A trespasser arrested in 1867, for example, was exempted from punishment altogether, and in general, if arrested intruders regretted their wrongdoing, they were simply released. In 1868, the Chosŏn court reduced the degree of punishment imposed on officials who overlooked transgressions within their jurisdictions, and by 1871 , such officials were not disciplined at all, even if people under their direct command were caught crossing the river illegally. ${ }^{38} \mathrm{In}$ fact, there was a well-known case that the Chosŏn local authorities openly encouraged Koreans to cultivate land north of the river. In 1880, Hong Namju, a local official of Hoeryŏng, pointed out that the lands north of the Tumen, long empty and off-limits, were now opened for Chinese immigrants, while Korean entrances were still regrettably restricted. Hong argued that since the Hoeryŏng people suffered from severe famine, they should be allowed to cross the river for cultivation and settlement. Eventually, during the years 1880 to 1881 , dozens of thousands of Korean farmers developed land, "hundreds $l i$ in length and dozens $l i$ in width," north of the Tumen. It was reported that people crossed the river every day as if the region to its north was not "outside" (K. oeji); more surprisingly, even Korean officials were dispatched to the area across the river to register land and collect taxes. ${ }^{39}$ This remarkable phenomenon of Korean immigration to the north of the Tumen was soon to be recognized in both Beijing and Seoul.

Korean immigrants who settled north of the Yalu and Tumen Rivers in the late nineteenth century did so for several reasons: domestic pressures due to population growth, the shortage of land in the Chosŏn northern region, and the 
attraction of new settlements in Qing Manchuria..$^{40}$ Most of all, it was the change in Qing policy in the northeast that made Koreans see the previously prohibited land as a settlement opportunity. As the Qing lifted its restrictions on access to the northeastern region, the area at the boundary with the Chosŏn was also exposed to the increased flow of migrants. People from both sides of the Yalu and Tumen Rivers had always crossed the rivers, and trespassing was a topic that the Qing and the Chosŏn had discussed throughout their long history. However, the wave of trespassing and settlement that took place in the late nineteenth century was a wholly new phenomenon. While previous illegal incursions had generally been limited in duration, undertaken mostly for the purposes of ginseng poaching and hunting, the late nineteenth-century intruders entered the areas near the Yalu and Tumen Rivers with the intention of staying for the long term.

\section{KOREAN SUBJECTS NORTH OF THE RIVER}

It was primarily the growing influence of the Western powers and Japan in the late nineteenth century that initiated the change in Qing perceptions of neighbor Chosŏn, which the Qing had always seen as subordinate. When European ships appeared at Korean shores, the Qing and Chosŏn courts were asked to explain the exact nature of their relationship. The process that ensued was surely confusing for all concerned. In the 1860 s, when French and American ships were involved in skirmishes off the coast of Korea, they assumed that the Qing, as the suzerain power, rather than the subordinate Chosŏn court, would take responsibility for the incidents. This assumption was supported by the Chosŏn court: it admitted its lack of experience and knowledge in foreign relations and asked the Qing to deal with the French in order to help the Chosŏn "live in eternal peace and reverently fulfill its tributary duties." ${ }^{41}$ However, the Qing government responded, "Even though it is surely subordinate to us, the Chosŏn is independent in its national affairs." ${ }^{2}$ In this confusing situation, Okamoto Takashi explains, both the Qing and the Chosŏn courts refused to take responsibility for dealing with the European powers, indicating that they understood their relationship differently from one another. The Chosŏn believed that its subordinate king was not allowed to establish relations with foreign countries without the recognition of the suzerain, while the Qing did not want to intervene in Chosŏn affairs, mostly to avoid trouble with the Western powers. ${ }^{43}$ However, the Japanese attack on Taiwan in 1874 and Japan's annexation of the Ryukyu Islands in 1879 prompted the Qing court to take the Chosŏn issue more seriously. In 1881, while negotiating the establishment of official diplomatic relations between the Chosŏn and European countries, the Qing diplomat Li Hongzhang (1823-1901) attempted to legalize Korea's subordinate status vis-à-vis Qing China and obtain international recognition of this special relationship. By this time, Qing policymakers sought to change the traditional 
Qing-Chosŏn relationship to include and accommodate more intervention of this kind. More than anything, as Kirk Larsen stresses, "Qing informal imperialism" was the outcome of the recognition that Qing-Chosŏn relations in the late nineteenth century had become multilateral, rather than bilateral, as they had been in the eighteenth century. ${ }^{44}$

Now, the issue of Korean immigrants north of the Tumen began to attract the attention of the Qing court. Before the early 1880s, the court seemed to pay little mind to reports of large numbers of Korean immigrants settling north of the Tumen River. Nor was there much of a response from the Shengjing or Jilin military governors, such as dispatching officials to evict the Korean trespassers or making an effort to send them back to the Chosŏn. However, soon after the land near the Tumen was open for Chinese farmers to settle, the Qing officials realized it had been already occupied by Korean immigrants. In the fall of 1881, acting upon Wu Dacheng's order, Hunchun officials investigated the areas around two hundred li north of the Tumen River and realized that several thousands of Korean farmers had developed as much as two thousand xiang of land. They also found that the number of Korean immigrants was continuing to grow, and that the Chosŏn officials of Hamgyŏng Province were even issuing land certificates to people in the area around Hunchun. ${ }^{45}$

Upon receiving such reports, the Jilin military governor Ming-an insisted that Chosŏn officials had no standing to discuss property matters in areas north of the Tumen River. He stressed that Korean immigrants were "children of the Heavenly Court" and therefore should be permitted to settle in Qing territory, instead of being sent back to the Chosŏn. He further claimed that these Koreans were China's subjects (Zhongguo zhi min), since they had settled on and cultivated China's land, and that they should be allowed to pay taxes to the Qing government and wear Chinese clothes. This following comment from the Board of Rites shows how the Qing court viewed Korean immigrants at this time:

The people now under discussion have already cultivated China's land; therefore, they should be considered China's subjects. According to the report of the military governor [Ming-an], they should be allowed to receive land certificates and pay taxes. In addition, following a designated period of time they should be included in our territory and taught to follow our rules and wear our clothing. They can be given temporary permission to keep their customs for a while, just as people in Yunnan and Guizhou were allowed to do. ${ }^{46}$

Agreeing with his officials' suggestions, the Guangxu emperor ordered that Korean settlers be issued land certificates and allowed to pay taxes. He further concluded that the Korean immigrants should be placed under the jurisdiction of Hunchun and Dunhua. This decision implied that Korean settlers to the north of the Tumen River would be regarded as Qing subjects. ${ }^{47}$ 
This plan of naturalizing immigrant Koreans as Qing subjects was met with strong opposition from the Chosŏn court, which found it unacceptable. If it condoned such a practice on the part of the Qing, the Chosŏn court reasoned, the Russians and the Japanese would be likely to raise similar demands:

[Chinese and Korean people] have different customs and cultures. Those people who crossed and settled in [Qing territory] were born and raised in our country [the Chosŏn]. It would be a problem on both sides of the boundary if these illegal settlers, after being assimilated with [the Qing people], did not observe [Qing] regulations and made trouble instead. The Chosŏn shares boundaries with Russia in the north and with Japan in the east; there are also some local people who trespassed [in these neighbors' territories] just like those who crossed the Tumen River. If these countries try to apply this precedent of the Heavenly Court [to their own boundaries], they will face the same troubles. ${ }^{48}$

Because of these concerns, the Chosŏn court insisted that the Guangxu emperor should order Qing officials in Hunchun and Dunhua to send the Korean immigrants back to their own country. The emperor eventually agreed to send Korean settlers back to the Chosŏn within a year: "It is proper that Korean wanderers who settled in Jilin should be sent back to their country. However, if they are immediately removed, they may not be able to make a living. Let them go back home within a year as a sign of my benevolence." 49

Nonetheless, Guangxu's decision to send Korean immigrants back to the Chosŏn did not mean that the Qing government simply gave up its efforts to extend its administrative authority to Koreans living in Qing territory. On the contrary, it began to issue new regulations applicable to Korean immigrants. In 1885, the Bureau of Trade and Commerce of Jilin and Korea (Ji Han tongshangju) was established and given charge of all affairs involving trade, taxation, and cultivation. The Qing government also built new offices at several locations north of the Tumen River, especially those that lay across the river from the locations of Chosŏn administrative offices, such as Hoeryŏng, Chongsŏng, and Onsŏng. The primary job of these new offices was to "govern the Korean immigrants [Hanmin] and settle disputes between Koreans and Chinese [Huamin]." Qing officials designated an area of land as wide as seven hundred $l i$ north of the Tumen River exclusively for Korean immigrants, who were granted a tax exemption for five years. These policies to authorize Korean settlement north of the river caused rapid growth in the number of Koreans emigrating across the Tumen River, so that by 1886 as many as 12,490 Koreans in 2,350 households had moved to the Hunchun area..$^{\circ}$

Meanwhile, the Chosŏn court's opposition to the Qing government's efforts to naturalize Korean immigrants as Qing subjects and its subsequent appeal to have such immigrants sent back to the Chosonn did not necessarily reflect the interests of the actual people who were the subject of these discussions between Beijing and 
Seoul. The Korean settlers north of the river believed that they had been forced to risk their lives and cross the river because of the long-lasting famine and perpetual hunger back home, and that they had had to endure many difficulties before settling down in the area. Not surprisingly, they did not want to give up their new homes. In 1883, when Qing officials in Dunhua informed Korean immigrants that they should go back to their own country after that year's harvest, the newcomers decided to "challenge the assumption inherent in the Qing demand," namely, that the area where they had settled lay outside Chosŏn territory.51 They made the claim that this area was, in fact, part of Chosŏn territory.

This argument was first addressed in 1883 by the local people in Chongsŏng, who wrote a petition to the Qing officials in Dunhua. It was an extremely unusual action, in that no local Korean had ever made direct contact with the Qing authorities. Their letter explained that there were actually two different rivers, both called "Tumen" in Chinese pronunciation but written in different characters; these two rivers were, in fact, distinguished from one another in Korean pronunciation as "Tomun" and "Tuman." They further argued that the Qing and Chosŏn territories were separated by the T'omun, not the Tuman, and that the land between the two rivers belonged to the Chosŏn. Their evidence was the stone marker of Mu-ke-deng, which had been erected in 1712 as a part of the investigation of Changbaishan and which proclaimed that the boundary of the two countries was demarcated by the Yalu River in the west and by the Tumen River in the east. The local Koreans asserted that the "Tumen River" inscribed in the stele was actually the T'omun River, not the Tuman..$^{52}$ Two months later, following the local residents' petition, the Chongsŏng prefect sent an official letter to the Qing counterpart in Dunhua, repeating the same argument that the T'omun and the Tuman were two different rivers. Based on this claim, the Chongsŏng prefect refused to cooperate with the Qing government's plan to send Korean immigrants back to the Chosŏn. ${ }^{53}$ Korean immigrants and the local Chosŏn authorities, for their part, firmly contended that the Tumen mentioned on the Mu-ke-deng's stele was the Hailanhe (K. Haeran'gang), another river located farther north from the Tuman, and that the land they settled in, therefore, was within Chosŏn territory. Finally, in 1885, the Chosŏn court proposed a boundary investigation to the Qing Board of Rites and the new office of foreign affairs, the Zongli yamen, asking that Qing officials be sent to the Tumen River. ${ }^{54}$ Attaching a copy of the old map of the area and a rubbing of the stele to a letter to the Qing court, the Korean officials proposed a joint field investigation to check the stele and the origin of the Tumen and to clarify the boundary of the two countries.5

Were the Tuman and T'omun in fact different rivers? The Songs of Flying Dragons (K. Yongbi ŏch’on'ga), published by the Chosŏn court in 1447, provides an explanation of the location of "T'omun," saying that "T'omun is the name of place north of the Tuman River, sixty li away from Kyŏngwŏn." ${ }_{56}$ This explanation shows 
that in the fifteenth century the Chosŏn court distinguished between "Tomun" and "Tuman." During the investigation of Changbaishan in 1712, however, Chosŏn officials used the names "Tomun" and "Tuman" interchangeably. Pak Kwŏn, the Chosŏn counterpart of Mu-ke-deng, recognized the "Tuman" as the boundary, while the Manchu official called it the "Tumen," but they did not disagree regarding which river the names denoted. The Chosŏn court officials were also well aware that "the so-called T"omun River in the letter [from the Qing] is the Chinese pronunciation of the Tuman (K. Tomun'gang chŭk hwaŭm Tuman'gang)." ${ }^{57}$ By the middle of the eighteenth century, the Chosŏn court was fully aware that the two rivers, the Tuman and the T'omun, were in reality one and the same river being called by two different names. In 1757, when the Qing court asked the Chosŏn court about the "Tuman" while investigating Korean trespassers, the latter court provided a detailed answer:

The names of the Tuman and T'omun Rivers are very close. The river in the north of the small country is called Tuman by [Korean] people. The Tuman that those criminals referred to is nothing but the Tomun, a name used by the great country. Han Sanglim [one of the trespassers] said "T'omun," while Cho Chayŏng [the other trespasser] said "Tuman," but it is the same river with two names. ${ }^{58}$

In addition, a Korean map, officially commissioned by the Chosŏn court during the years 1777 to 1791 and titled "Map of the Northwestern Boundary" (K. Sŏbuk kyedo), demonstrates the contemporaneous Korean understanding that the T'omun and the Tuman were the same river..$^{59}$

By the late nineteenth century, however, when the location of the Tumen River became a source of conflict with the Qing, the Chosŏn court either forgot or ignored the geographic knowledge that it had possessed in the eighteenth century and decided to accept the arguments made by the local residents in the area. Interestingly, this shows that the Koreans selected, recalled, and reinterpreted their own geographic knowledge of their territory in accordance with the new situation that they faced in the late nineteenth century. The Chosŏn court in the early eighteenth century had been willing to ignore the fact that the imperial emissary had located the Tumen riverhead in the wrong place, whereas the Koreans in the late nineteenth century endeavored to find the exact location of the same riverhead. The eighteenth-century Chosŏn court had been reluctant to share geographic information about the boundary with the Qing; by contrast, the late nineteenthcentury Koreans took the initiative to clarify the boundary. The dramatic shift in the Chosŏn attitude shows that Korean ideas about territorial boundaries had undergone a profound change by the late nineteenth century, the era in which both parties' willingness to tolerate the existence of the borderland-that is, the ambiguity of the exact location of the boundary and the uninhabited buffer zone around it-was about to end. 
It was the stone stele of Mu-ke-deng that provided the two sides with the source of their disputes over the exact location of the boundary. Officials from the two countries held very different interpretations of the stone marker built in 1712. Chosŏn officials stressed that Mu-ke-deng, the imperial emissary of the Kangxi emperor, had investigated the origins of the rivers specifically in order to clarify the Qing-Chosonn boundary, and they maintained that the stele was the outcome of his research. Therefore, if there was any uncertainty about the boundary, Koreans claimed, the stele should be used as the standard of judgment. In contrast to the Chosonn officials, who were firmly convinced of the authority of the stele, Qing officials did not think that the stele provided indisputable evidence of the location of the boundary ${ }^{60}$ While Chosŏn court officials were widely aware of $\mathrm{Mu}$-ke-deng's investigation and the resulting stele, only a few individuals at the Qing court had paid attention to the stele's erection. The stele was not well known or much discussed among Qing scholars of geography, and this lack of information explains, in part, why Qing officials gave so little credence to it. Furthermore, most of the documents related to Mu-ke-deng's travels and investigation had already been lost, so that Qing officials did not have much evidence with which to verify the legitimacy of the stele. The Qing officials also emphasized that the name Tumen came from a Manchu word tumen, which means "ten thousand," and the river happened to be known by two names thanks to the use of different Chinese characters. From the Qing point of view, then, the boundary should be established on the basis of the origin of the river, not on the basis of an old, unreliable stone marker. ${ }^{61}$

\section{DEMARCATING THE BORDER}

It took two years before the Qing and Chosonn governments finally launched a joint survey of the boundary. The question about the exact location of the Tumen riverhead was first raised by local Koreans, then shared with the Chosonn local officials, and finally reached Seoul and Beijing. The Chosŏn authorities of Chongsŏng had first proposed such a survey to their Qing counterpart in Dunhua in July 1883; then, in August 1885, the Chosŏn court sent an official letter to the Qing Board of Rites and the Zongli yamen arguing that the Tuman and the Tomun were two different rivers and thus it was necessary to investigate the area. Finally, in September 1885, Li Hongzhang responded to the Chosŏn court, agreeing to conduct a joint Qing-Chosŏn survey. ${ }^{62}$ Two months later, November 6, 1885, Qing inspectors went to Hoeryŏng to meet with their Chosŏn counterparts. The main issue to resolve was the question of whether the Tuman and the Tomun were in fact one and the same river. The Qing officials argued that they were, but their Chosonn counterparts disagreed. Another disagreement concerned the question of what should be the reference point for determining the location of the boundary: the river or the 
stele. The Qing officials claimed that since the stream that passed east of the stele flowed into the Sungari River, not into the Tumen, the stele of Mu-ke-deng failed to provide accurate geographical information. In response, the Korean inspectors referred to the official documents exchanged between the two courts at the time when the stele was erected and insisted that $\mathrm{Mu}$-ke-deng's investigation and stele were legitimate and reliable criteria for locating the boundary. Despite two months of surveying and discussions, the two sides did not reach an agreement: the negotiations failed, and the officials returned to their respective countries. ${ }^{63}$

Two years later, on April 29, 1887, the Qing and Chosŏn courts resumed the boundary survey. This time it was the Jilin military governor who insisted on the urgency of the survey, as Korean immigration and settlement had continued after the failure of the earlier survey effort and conflicts were increasing between Chinese and Korean residents over land cultivation, causing serious tensions in local societies. ${ }^{64}$ In this second round of discussions, the Chosŏn officials withdrew their initial assertion that the T'omun and the Tuman were distinct rivers. In fact, the Korean inspector, Yi Chungha (1846-1917), had been aware that it was the same river during his first investigation of 1885 . Eventually the Chosŏn court official, Kim Yunsik (1835-1922), sent a letter to the Yuan Shikai (1859-1916) as early as October 1886 admitting that "the T'omun and the Tuman were the same river with different names." ${ }^{35}$ Instead, what became the main issue in the second boundary survey was the location of the Tumen River's source. The Chosonn officials identified Hongtushan shui (K. Hongtosan su), one of the streams flowing from Changbaishan, as the origin of the Tumen River, while the Qing counterproposed Shiyishui (K. Sŏgŭlsu), another stream from the mountain, as the source-a choice that, if used to determine the boundary, would allow the Qing to claim the entire Changbaishan range and, as the Qing official pointed out, "the sacred birthplace [faxiang zhi ben] will not be violated." ${ }^{66}$ The Chosŏn refused to accept Shiyishui as the origin of the Tumen, asserting that "there is no evidence to prove it in any document." In the end, after another one and a half months of surveys and debates, the two sides again failed to reach an agreement about the boundary. ${ }^{67}$

The Qing and Chosŏn officials were all well aware of the significance of territorial boundaries and sovereignty, an issue that was newly raised in modern international relations. While Yi Chungha knew that Hongtushan shui was only a few $l i$ away from Shiyishui and the land between them was actually useless, he still insisted that Hongtushan shui be the boundary, because "even a tiny piece of state territory is so important." ${ }^{68}$ The fact that the Chosŏn court demanded field investigations in order to demarcate the boundary demonstrates that the Koreans had begun to recognize the system of international relations in which a country is defined by distinct boundaries and territorial sovereignty. These changes in Korean views of the Qing are well reflected in a memorial from Chi Kyŏngyong, a local official in the northern region, to the Chosón court in 1884. First stating that the 


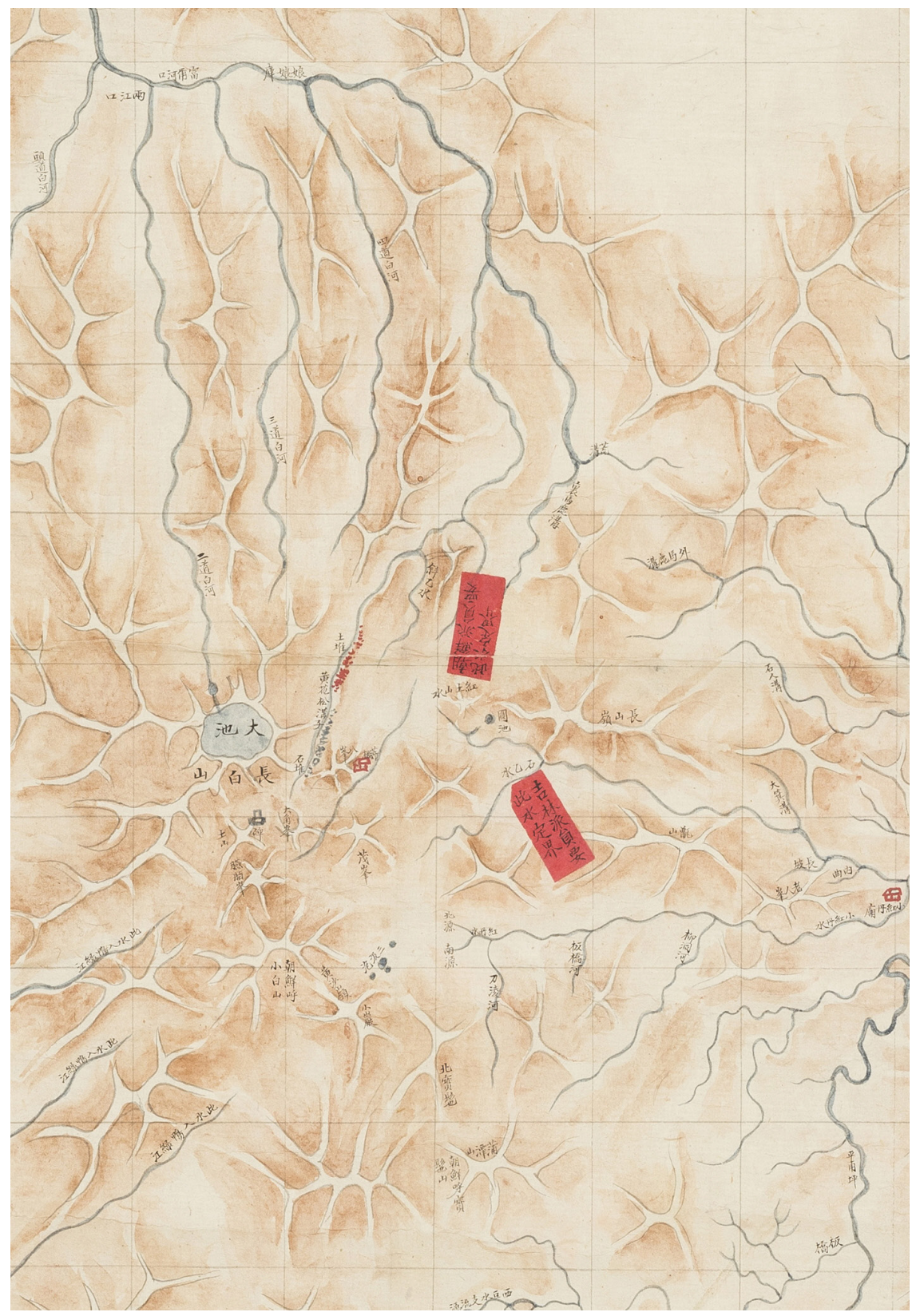

FIGURE 12. Changbaishan and the Tumen riverhead. Detail from Paektusan chŏnggyebi chido (maps of the stele of Changbaishan), 1887. Manuscript, $54.2 \times 99 \mathrm{~cm}$. Kyujanggak Institute for Korean Studies of Seoul National University, no. ko-ch'uk 26675. Used with permission. 
Qing-Chosŏn boundary lay along the Hailanhe, not the Tumen River, Chi then contended that the Chosŏn should make an open claim to the Qing, especially since at the time "all the states in the world are in discussion with one another, whether they are big or small." 69

Among Korean intellectuals, various conflicting ideas-strong nationalism, traditional Sinocentrism, and a limited understanding of the international world order-were held in an uneven fashion. As Andre Schmid stresses, Qing-Chosŏn boundary negotiations in the late 188 os demonstrate how the tributary relationship maintained its unique features, as well as how it was challenged and ultimately collapsed. Both sides frequently used old terms, such as "great country" (C. daguo; K. taeguk) and "small country" (C. xiaobang; K. sobang). ${ }^{70}$ Using the same methods by which the Chosŏn kings had long appealed to the Qing emperor-emphasizing the old traditions of the tributary relationship between the two countries-the Korean inspector argued that all of the characters inscribed on the stele were included in the documents of the "Heavenly Court," representing an absolute verification that should not be disputed or disrespected. ${ }^{71}$ As a representative of the Chosŏn court, Yi Chungha tried to challenge Qing authority to dispute the Chosŏn state's territorial sovereignty, but what he relied on in his negotiations with the neighboring country was the age-old rhetoric of the special relationship of the Chosŏn with the Qing. The expectation of imperial benevolence toward the Chosŏn was clearly revealed in Kim Yunsik's petition to Yuan Shikai for "borrowing [Qing] land for [Korean] settlement” (K. chaji anch'i), which asked the Qing for permission for the Korean farmers north of the Tumen to stay, while the Chosŏn authorities be given the right to collect tax from them. The tradition of asymmetrical relations between the Qing and the Chosŏn, and the recognition of territorial sovereignty, coexisted in Kim's impractical suggestion to borrow the Qing land for the Korean immigrants. ${ }^{2}$ As Akizuki Nozomi points out, "By the 188 os, the Chosŏn court did not fully understand that the modern system of international relations was more or less in conflict with the tradition of Sinocentricism."73

During the 188 os and 1890 os, the Qing court continued to undertake a major change in policy toward people and territory in the northeast. The new policy of encouraging people to settle at the northeastern margins eventually led to the invitation of Korean farmers into Qing territory north of the Tumen, a plan that was believed to benefit the Qing government through the collection of taxes and the improvement of security at the boundary. During the boundary surveys and discussions of the late 188 os, the Qing continued to invite Korean immigrants to Qing territory, making them into Qing subjects and requiring them to adopt Qing customs of dress and appearance. ${ }^{74}$ As Yi Chiyŏng points out, the Qing at first considered Korean immigrants "foreigners living in our territory," while the Chosŏn regarded them as "our subjects living in foreign territory." Later, both sides argued that these Korean settlers were "our subjects in our territory." 75 These changes in 
the respective views of the Qing and the Chosŏn regarding the Korean immigrants in the area north of the rivers are another indicator of the transformation of their ideas about territory and sovereignty. The two states were no longer willing to accept the existence of an unclear buffer zone; instead, they sought to claim the right to rule both the people and the territory demarcated by a clear border. The Qing authorities tried to turn Korean immigrants into Qing subjects by listing them in Qing registers. For their part, the Chosŏn endeavored to resolve the problem of Korean settlers north of the Tumen, first, by claiming the territory as part of the Chosŏn realm, and later, by borrowing the land from the Qing for Korean immigrants. The series of Qing-Chosŏn boundary negotiations was provoked by illegal Korean immigration in the area that the two states had agreed to keep uninhabited, a phenomenon that led them to reconsider the empty buffer zone laying between them-more precisely, territorial sovereignty. This transition was clearly related to the emergence of the modern notion of national space as the core of a state's sovereignty. The empty buffer zone that blurred the exact limits of the two states' territories suddenly was undermining their power and authority and was thus no longer acceptable: "Sovereignty was something to be performed, and borders were to be implemented." ${ }^{76}$

It was the Sino-Japanese War of 1895 that officially ended the traditional tributary relationship between the Qing and the Chosŏn. The Qing army was defeated by Japanese troops, a clear affirmation that the Qing had no military or legal power to claim continued suzerainty over the Chosŏn. With the end of the war, the Qing court lost all of the exclusive privileges it had commanded from the Chosonn court, including Korean tributary missions to the Qing emperor. The practices that had both embodied and symbolized the hierarchical relationship between the Qing and Chosŏn courts thus officially came to an end. ${ }^{77}$ Four years after the end of Sino-Japanese War, in 1899, the Qing and Chosŏn courts reached the Treaty of Seoul, the twelfth article of which prohibited any further Korean trespassing in Qing territory, while guaranteeing the security of those Koreans who had already settled there. ${ }^{78}$ In the meantime, the repatriation of Korean immigrants living north of the Tumen back to the Chosŏn was continuously delayed.

The Boxer Rebellion of 1900 expedited the fall of the Qing dynasty and prompted foreign expansion into China proper as well as into its peripheries. Taking advantage of the crisis, Russia quickly occupied Manchuria, including several locations near the Korean boundary. The Russian occupation of Manchuria provided Korea with an opportunity to extend its authority in the Kando region north of the Tumen River, as the Qing forces were largely constrained by Russian troops and Russia wanted to act favorably toward Korea in order to check Japanese movements in the Korean peninsula. The Korean government hoped to settle its boundary dispute with the Qing court by negotiating with Russia. ${ }^{79}$ In an attempt to consolidate its rule over the Kando region, the Korean government sent 
a special inspector in 1902 to investigate the number of Korean households and people living there. However, the increasing competition between Russia and Japan in Manchuria dashed Korea's hopes of expanding its territory northward. By defeating Russia in the Russo-Japanese War of 1904 and making Korea into a Japanese protectorate in 1905, Japan took the lead in the boundary negotiations between China and Korea. ${ }^{80}$

In 1906, the Japanese established a police substation in Longjing and announced that Kando should be included in Korean territory; the following year, Japan further claimed that the Koreans had no obligation to follow Qing regulations. The Qing court rejected the Japanese claim that Kando was Korean territory, insisting on its exclusive right to rule the people and territory north of the Tumen River. On September 4, 1909, after several years of negotiations, China finally signed what became known as the "six treaties on the Three Eastern Provinces" (Dong sansheng liu'an), which allowed Japan to build railways and develop mines in Manchuria. One of the treaties was the "arrangement on the Tumen boundary between China and Korea" (Tumenjiang Zhong Han jiewu tiaokuan), also widely known as the Agreement of Kando, which secured China's territorial claims to the Kando region. This arrangement stated in its first article that "the China-Korean boundary is the Tumen and the origin of the river is Shiyishui," further explaining in following articles that Korean immigrants north of the Tumen should be governed by Chinese laws and included within the jurisdictions of Chinese officials. ${ }^{81}$ By the time the Chinese-Korean boundary was finally confirmed, however, both the Qing and the Chosonn courts were doomed. As the borderland they had shared for so long was replaced by a border, the old Qing and Chosŏn states were destined to disappear. The Qing empire and the Chosonn kingdom could tolerate the existence of a borderland, but modern China and Korea needed a clear border between them.

Ginseng in Manchuria had been carefully managed throughout the Qing period by a well-developed system of imperial foraging. Such systemic exploitations of ginseng for centuries eventually brought about the depletion of wild ginseng to the extent that the state could not maintain its ginseng monopoly. And as ginseng disappeared in the Manchurian mountains, it was no longer ginseng poachers or illegal sable hunters who violated the restrictions on entering the region; instead, Chinese farmers came in search of land. Once providing wealth and prestige for the Manchus, Manchuria gradually came under the plow of Chinese farmers. As the Qing decided to open the northeastern margins to civilian settlement for the purpose of protecting their territory from foreign aggression, the flow of Chinese immigration reached the Yalu and Tumen Rivers, once a ginseng producing area that had been closed to civilian settlement. Under the strong pressure of 
immigrants, the agreement between the Qing and the Choson for the uninhabited empty zone at the boundary-one feature of the borderland-was no longer maintained. Even as the Qing authorities tried to develop the land near the Tumen River, they found it already occupied by Korean immigrants. Given the competition for land and people, they had to solve the ambiguity of the exact location of the boundary-the other feature of the borderland. The joint investigations of the Tumen riverhead in the 1880s were an announcement that the Qing and the Chosŏn could no longer maintain the borderland that they had shared for centuries. As the ideas and practices of territory and sovereignty transformed, the borderland was replaced by a border. 
